\title{
Fostering EFL Learners' Reading Comprehension: Animation Film Technique
}

\author{
Asefeh Torabian (Corresponding author) \\ Department of Foreign Languages, Kerman Branch, Islamic Azad University, Kerman, Iran \\ E-mail: mnarafshan@yahoo.com \\ Massoud Tajadini \\ Department of Foreign Languages, Kerman Branch, Islamic Azad University, Kerman, Iran
}

Doi:10.7575/aiac.alls.v.8n.2p.55

URL: http://dx.doi.org/10.7575/aiac.alls.v.8n.2p.55
Received: 06/02/2017

Accepted: 29/03/2017

\begin{abstract}
The current study investigated the effect of implementing animation films on developing reading comprehension texts among EFL learners of a language institute in Kerman. For this purpose, two groups of pre-intermediate EFL learners were chosen (30 participants in each group). After three months of instruction, twice a week, 2 story books named the "Good Dinosaur" and "Little Prince" including totally 20 chapters in both groups and animation films including 60 minutes divided into 6 to 7 minutes in each session in experimental group were presented. To estimate the primary knowledge of the subjects, a pretest was taken from both groups and after the experiment came to an end, a posttest was followed. The result revealed that a meaningful relationship could be identified between the procedures incorporated for both groups. However, the experimental group achieved higher degree of achievement using animation films presented to them by scoring higher in the total mean and also, interview participants were satisfied with the use of animation films in the reading class.
\end{abstract}

Keywords: Animation film, reading comprehension, EFL learners

\section{Introduction}

Since reading is an important language skill and a highly-complicated act, students can struggle in many subjects without adequate reading comprehension skills. Lack of adequate knowledge in reading comprehension is a serious problem that students suffer from. However, weakness in understanding what they read may not be attributed to lack of intelligences or weakness of mental abilities but to being not familiar with reading comprehension (Bader El-Dean, 2009). Nabeel(1994) asserted that the announcement of a reading assignment in some English classless provokes complains from students as they envision the long time it will require, the laborious task of looking up words' meanings in the dictionary. What makes matters worse is that after such boring task the students fail to comprehend the text.

Rog (2001) believed that using animation films increases the learners' concepts about print, story structure and other elements of text and provides learners with a wealth of information about the processes and functions of written language. It gives learners new understandings on various subjects that they encounter only through books (Terblanche, 2002). Using animation films puts a high premium on student involvement (Hennings, 1994). Moreover, watching animation films which makes enjoyment improves the chances that learners become lifelong readers; increasing the chances that reading life doesn't end with high school graduation (Kimmel and Segal, 1983). Atwell (1987) mentioned that the students are affected by using animation films and that these activities motivate them to borrow the books that are shared, to locate other books by the same author, and to respond actively and personally with texts.

Comprehension is certainly the most important reading skill addressed by most scholars. Using animation films has positive effects on the development of reading comprehension. Reading comprehension has been shown to improve in various ways when using animation films is used in the classroom (Primamore, 1994). As cited by Trelease(1994), one way is when one book is accompanied by film, often students will seek out the sequels to that book. Comprehension of the sequels is increased because interest and background knowledge have been introduced to the students.

The effectiveness of using animation films has been demonstrated in the results of over 75 years of educational research (Wood, 1994).Gold and Gibson, (2001) emphasized that using animation films is the foundation of reading comprehension development. They also state that animation films transfer students from the theoretical to applied knowledge and from hypothetical situation to real life situations. It is believed that training students to practice reading short stories facilitates reading comprehension. (Neumann et al, 2000). Moreover, reading short stories motivates students to infer the hidden meaning to evaluate and judge characters and situations. Precisely, learners practice low cognitive thinking skills, knowledge comprehension application and high order thinking skills analysis, and evaluation (Harmer, 2001). It reveals the rewards of reading and develops the learners' interests in books and desire to be a reader (Mooney, 1990). Trelease(1994) said that using animation films fosters the desire to read reading comprehensions. 
Using animation films encourages learners to grow as readers and broadens the types of reading they choose to read (Harste et al., 1988). The single most important activity for building knowledge required for eventual success in reading is using animation films with the relative reading comprehension (Anderson et al., 1985). Moreover, Beach(1993) stated that animation films are a teaching technique that supports both the affective and cognitive aspects of the learning process. That is, it brings a clear life to the class environment. Animation films introduce reading comprehension texts provided with motion, sounds and colors that attract the students to live with the characters and share their roles. This is strong type of motivation which facilitates learning, activates learners' imagination, prediction and high order thinking skills (Schmitd, 1997). Consequently, this study probes the effect of implementing animation films on developing reading comprehension texts among EFL learners.

\section{Theoretical Framework of the Study}

The theoretical framework of this study is Dual coding theory proposed by Paivio(1986).In this theory, imagery is mainly important in facilitating long-term retention. Shaping images facilitates learning by providing the learner with a meaningful representation of the material being studied. Paivio (1986) has stressed that "imagery contributes to reading comprehension" (p.441). Moreover, he regards imagery as potentially facilitative in the retrieval of items from memory as well as in understanding and paraphrasing sentences. Dual Coding Theory (DCT) identifies two modes of processing information: imagery and language. Students who, according to the theory, utilize both modes of processing simultaneously have better comprehension due to better use of cognitive processes. On the basis of this theory, which suggests that verbal and pictorial memory exist as two interlinked but discrete long-term memory systems, Paivio (1986) reveals a distinction between the manner concrete words, phrases or sentences and abstract ones are stored in the readers' mind. It means that concrete phrases or sentences, like concrete words, can be coded and stored in memory not only verbally but also in the form of imagery. On the whole, the ideas proposed by Paivio will constitute the basis and framework of the present study because it will establish a strong basis for learning reading comprehension among EFL learners.

\section{Literature Review}

Different studies have discussed about using literature in language classrooms. For example, Maley (1989, as cited in Hismanoglu, 2005) lists the following reasons for using literature in the language classroom: Universality, Nontriviality, Personal Relevance, Variety, Interest, Economy and Suggestive Power, Ambiguity. Parkinson and Thomas, 2000, as cited in Sell, 2005) also made a list of some advantages for incorporating this sort of technique: Linguistic pattern Open to explanation and Convenience, Cultural enrichment, Extension of linguistic competence, Authenticity, Memorability, Rhythmic resource, Mental training, Motivating material. In spite researchers mentioned some usefulness for incorporating this technique in second language teaching, but as Chiang (2007) claimed there are the other major advantages for using literature into English language teaching. this technique is mentioned as a real material in second language classrooms. Hismanoglu (2005) researched this kind of texts are written for first language learners, they are not for educational aims. Sell (2005) said standard FL texts for non-real material. She also named that some issues are not suitable to the second language learners. They address the authentic topics that learners will face them in real-life. Textbooks are full of fiction and unreal materials. Studying literature get learners with the opportunity to practice the language skills. Teaching literature foster all four skills. Based on Hismanoglu (2005) in literary text students should know both syntactic structure and discourse. Literary text needs effort for comprehending. Therefore, it will help learners to become more challengeable. McKay (2001) argued that literary texts can be great for four language skills. In reading comprehension, literary texts encourage interest and closer reading of the texts, as well as integrating the four skills during reading practice. He also said that literature can developed listening skills. Such as a listening part an unheard short story can be read aloud to the students and then teacher makes some questions to students about comprehension of the story. Stern (2001) maintains that literature can be practiced as a pattern and subject issue for writing. He points out literature as great material for speaking skills by generating discussions about different elements of literary texts such as characters, plot and themes. literature develop cultural awareness. Based on Sell (2005) them with apposite pragmatic and socio-psychological components to build important identities which will enable their socialization in the target culture and improve the effectiveness with which they attend in that culture". He also said that literary text both make language learners familiar with English culture by using famous literary text from other languages it can also increase awareness of different cultures. literature improve interaction. Chiang (2007) claimed "Literary texts are important as multiple layers of meaning, and can be effectively mentioned for discussions. when literature has the potential to be a tool of great cooperating in second language classrooms, its potential can be best realized while readers are encouraged to develop personal responses to the reading from multiple aspects and to share them in discussions".

McCormick (1977) indicated that 4 and 6th-grdares have shown learners who cooperating film technique through several months demonstrate important achievements in reading comprehension, and words. It was also explored that all learners benefited significantly as compared to the control groups, who were read only the short stories.

Williamson (1988) emphasized that foreign teachers should use a technique such as film in their classes because the students get a better feeling for using the language. Using film for students is also a motivation enhancement.

Furthermore, Zaytoun (1988) believed that in order to develop in comprehension, the teacher should put the students to authentic situations in which speakers are native. He stated that the teachers should say about family, friend, personal experiences, , or even ascendants about common events or controversial topics. In this task, the teacher 
encourages the students to native speech with unlimited structure, strange words and expressions and knows many different conditions of culture.

Elley (1991) claimed that being learner to a wide rank of pictorial storybooks encourage learners to learn the target language more quickly. She also found that while learners are integrated in meaningful text lack of the deficiency of structure and vocabulary, they are likely to learn the language incidentally and develop positive attitudes towards books and school. In addition, Elley said that cooperating film can be an important material of vocabulary acquisition and she resulted by showing that the influence of film is clear in the language learning steps.

Warwick (1992) reported the exploring of a comprehensive study that was completed during 1990 to 1991 . It concluded between thirty-two countries. The study involved the reading achievement of 21,000 students at the age of 9 to 14 years old. The conclusion indicated that the major nations were Finland, United States, Sweden and France, respectively. The important tips found to create these high gain scores within years were: cooperating film.

A study investigated about involving film on comprehension and language among English foreign language learners by Vivas (1996). The conclusion of this study showed that listening to whom read the stories loudly helps learners develop using listening and gives learners specific training about comprehension through attractive and meaningful of stories.

Amer (1997) found the influence of the film through language learners reading comprehension. in this study is taken part Seventy-five learners. in experimental group, film before reading the story was used but in control group reading the story has been done. In this research, two sorts of dependent measures were used: a story frame test and a multiplechoice test. Conclusion of this study is that the experimental group performed better than the control group on both measures. that showed cooperating film may have a positive effect on learners' reading comprehension significantly.

Beck and Mckeown (1999) researched about film and reading comprehension. result indicated that film affected on reading comprehension positively.

Campbell (2001) emphasized that film creates arts and crafts, readings, discourse, writing, and song. He believed that film provides some sorts of literacy for learners: learners learn about literacy in adult who provides a pattern of reading, make an understanding of how do functions and how it is applied, develop a understanding of letters and phonetics relation, learn new words, new sentences; and discourse patterns, learn about the structure of stories and develop a positive attitude toward books. Moreover, he mentioned film can be useful such an ideal tip for further learning in many schema areas.

McCarthy et al. (2001) improved $1^{\text {st }}$ through $5^{\text {th }}$, grade students in reading comprehension and the learner's attitudes toward reading short stories by film. the study showed that film encourage learners to foster their information about different topics, know story patterns, learn many words, enhance knowledge about language structure, increase getting information of the reading steps, and knowing reading as an attractive exercise. The results showed that the desire of learners for reading developed and students habit to read were influenced positively.

A project designed by Wood and Salvetti (2001) called the 'Project Story Boost' which help learners being failure due to poverty and provided some sessions by cooperating film with relative text for a period of months. Learners who took part in this project improved in vocabulary enhancement and attending in reading and writing activities discussions, and. Learners who stayed more in this project fostered in talking about stories by ordering words, details and events of the stories. The important factors of film were interpreted to the lower grades where students got point higher in comprehension and reading fluency than students who did not participate in the project. The same as Hargrave and Sénéchal (2000) investigated whether learners who participate orally within storybook reading made successfulness in language or not. it was discovered that learners who responded to open-ended questions around the text had better finding than learners who just read the stories during a month; learners achieved an increase in words which usually were during one season.

Queini et al. (2008) studied for several months with learners at the age of fifty-three years-old to research the impact of film on the vocabulary of learners' development and comprehension skills. This technique consisted of cooperating film before reading comprehension of short stories and explaining strange vocabulary. Learners were involved in discourse about the text, encourage them to think logically and critically. results showed achievements in reading comprehension skills in learners' vocabulary. while learners are attending in speaking about stories during the film, they were able to use the difficult words and integrate analysis and synthesis.

Herron and Seay (1991) investigated the research on using video in reading comprehension texts. The research showed that the experimental group performed significantly better by using video and audio than the control group in which had traditional training.

A research was studied by Joseph R. Weyers (1999) is about an authentic material such as soap opera to know whether this material can improve students reading comprehension and develop their oral skills or not. For his research, he used the control group and the experimental group. The experiment was during 2 terms. All students took the pre- and posttreatment tests. In this study, learners in the experimental group watched two parts of a film each week. Before starting to watch each part, the students were given a summery. At the end of the research, result suggested that using this sort of technique is a valuable material in increasing the students' reading comprehension skills. 
4. Objectives and Research Questions of the Study

The present study attempts to investigate the effect of using animation films on reading comprehension among pre intermediate students. Thus, it is hoped that using animation film in the classroom would help students improve their reading comprehension abilities and also it means to explore the attitudes of the learners on the use of animation films in the reading class.

The study was designed to provide the answers to the following research questions:

Q1: What is the effect of using animation films on reading comprehension of short stories among EFL learners?

Q2: what is EFL learner's attitude towards using animation films in reading comprehension classrooms?

\section{Method}

The study was an experimental method of research.

\subsection{Participants}

The statistical population of the study was made up of 85 pre-intermediate EFL learners in Shokouh Language Institute in Kerman. To homogenize the study subjects, the Oxford Placement Test was administered and only those subjects whose score fell one standard deviation above and below the mean were selected for the study. They made a population of 60 subjects who were randomly classified into two groups, each group included 30 female students, aged 13 to 15. They constituted the experimental and control group for the study. The reason for selecting these learners is that they had already received the required instruction to learn English reading comprehension.

\subsection{Instrumentation}

The researcher used several types of instruments to collect the required data.

\subsubsection{Oxford Placement Test}

Primarily, The Oxford Placement Test was administered to homogenize the study subjects. This test contains 100 items on basic and elementary grammar, vocabulary, and reading comprehension in the form of multiple choice tests and limited completion tests.

\subsubsection{Reading comprehension Test}

The other instrument was using one set of reading comprehension tests which were used to tap the initial reading comprehensions knowledge of the learners in both groups: pre and post reading comprehension tests. All tests were extracted from the teachers' books that are available to the language teachers in Shokouh Language Institute. In fact, they were chosen from the test collection of the textbooks which are normally taught in the language institute. They are supplementary sources that tend to improve the reading comprehension knowledge of the learners of English by providing a lot of multiple choice test items.

Each pre and posttest contained 60 items which were constructed in the form of multiple choice tests and were accompanied with an answer sheet, the technique which made the scoring reliable, easy and economical. Also to make sure of the validity of the questions, the tests were given to three colleagues of the researcher. They were asked to read them and tick any irrelevant item. A few irrelevant ones were identified and were excluded. To ensure the test reliability, the researcher used test-retest method. To do so, ten similar learners were asked to answer the questions of the intended tests. After two weeks, the test was repeated with the same learners. Using Karl Pearson mathematical parameter, the test was proved to be reliable at .78 .

\subsubsection{Interview}

The researcher carried out a semi -structure interview to seek the attitudes of the learners. The participants were interviewed one by one and their voices recorded and later on they were extracted and reflected for analysis.

\section{Result}

In This part, the data investigating the impact of surfing blogs on EFL learners' reading comprehension is presented and analyzed.

6.1 What is the difference between control and experimental group's reading comprehension in Pre-test?

To investigate this question, the independent sample $\mathrm{T}$ test was used (table 3.1.) Regarding the $\mathrm{P}$ - value that is more than $0.05(\mathrm{P}-$ value $=0.5)$, it can be said with more than $95 \%$ confidence, that mean of reading comprehension in control and experimental group in pre-test was not significantly different $(t=0.74, d f=58, p>0.05)$.

Table 1. Independent-sample T Test of Reading Comprehension in Control and Experimental Group in Pre-test

\begin{tabular}{|c|c|c|c|c|c|c|}
\hline & \multicolumn{3}{|c|}{ Reading Comprehension } & T-Test & Df & P-Value \\
\hline Group & $\begin{array}{l}\text { Total } \\
\text { number }\end{array}$ & Mean & Std.Deviation & -0.74 & 58 & 0.5 \\
\hline Control & 30 & 12.93 & 1.70 & & & \\
\hline Experimental & 30 & 13.27 & 1.78 & & & \\
\hline
\end{tabular}


6.2 What is the difference between control and experimental group's reading comprehension in post-test?

To investigate this question, the Independent Sample $\mathrm{T}$ test was used (table 3.2). Regarding the $\mathrm{P}-$ value that is less than 0.01 ( $\mathrm{P}$ - Value 0.0005), it can be said with more than $99 \%$ confidence, that mean of reading comprehension in control and experimental group in post test was significantly different $(\mathrm{t}=-3.98, \mathrm{df}=58, \mathrm{p}<0.01)$. It means that the mean of reading comprehension in experimental group in post test $(\mathrm{M} 2=15.90, \mathrm{SD} 2=1.81)$ was significantly more than control group $(\mathrm{M} 1=14.17, \mathrm{SD} 1=1.56)$. Additionally, the effect size was $\mathrm{ES}=1.03$ and $\mathrm{r}=0.458$. It could be said that the effect size was moderate. It showed that the control groups' reading comprehension changed moderatly in post test.

Table 2. Independent - Sample T Test of Reading Comprehension in control and experimental Group in post-test

\begin{tabular}{lllllll}
\hline & \multicolumn{3}{c}{ Reading Comprehension } & T-Test & Df & P-Value \\
\cline { 1 - 5 } Group & $\begin{array}{l}\text { Total } \\
\text { number }\end{array}$ & Mean & Std.Deviation & -3.98 & 58 & 0.0005 \\
\cline { 1 - 5 } Control & 30 & 14.17 & 1.56 & & & \\
\cline { 1 - 5 } Experimental & 30 & 15.90 & 1.81 & & \\
\hline
\end{tabular}

\subsection{What is the difference between control group's reading comprehension in pre-test and post-test?}

To investigate this question, the paired $\mathrm{T}$ test was used (table 3.3). Regarding the $\mathrm{P}-$ value that is less than 0.01 ( $\mathrm{p}-$ value $=0.0005$ ), it can be said with more than $99 \%$ confidence, that mean of reading comprehension in control group was not significantly different in pre-test and post-test $(\mathrm{t}=-5.08, \mathrm{df}=29 . \mathrm{P}<0.01)$. It means that the mean of reading comprehension in control group in post test $(\mathrm{M} 2=14.17, \mathrm{SD} 2=1.56)$ was not significantly more than the pre- test $(\mathrm{M} 1=12.93, \mathrm{SD} 1=1.70)$. Additionally, the effect size was $\mathrm{ES}=0.76$ and $\mathrm{r}=0.354$ It could be said that the effect size was moderate. It showed that the control groups' reading comprehension changed moderately in post test.

Table 3. Paired T Test of Reading Comprehension Scores in Control Group in pre-test and post-test

\begin{tabular}{lllllll}
\hline Time & $\mathrm{N}$ & Mean & Std.Deviation & T-Test & df & P-Value \\
\cline { 1 - 4 } pre-test & 30 & 12.93 & 1.70 & -5.08 & 29 & 0.0005 \\
\cline { 1 - 4 } post-test & 30 & 14.17 & 1.56 & & \\
\hline
\end{tabular}

\subsection{What is the difference between experimental group's reading comprehension in pre-test and post-test?}

To investigate this question, the paired $\mathrm{T}$ test was used (table 3.4). Regarding the $\mathrm{p}-$ value that is less than 0.01 ( $\mathrm{p}-$ value $=0.0005)$, it can be said with more than $99 \%$ confidence, that mean of reading comprehension in experimental group was significantly different in pre-test and post-test $(\mathrm{t}=-11.33, \mathrm{df}=29, \mathrm{p}<0.01)$. It means that the mean of reading comprehension in experimental group in post-test $(\mathrm{M} 2=15.90, \mathrm{SD} 2=1.81)$ was more than pre-test $(\mathrm{M} 1=13.27$ ,SD1=1.78). Additionally, the effect size was $E S=0.592$ and $r=0.57$. It could be said that the effect size was large. It showed that the experimental group's reading comprehension changed significantly in post test.

Table 4. Paired T Test of Reading Comprehension Scores in Experimental Group in pre-test and post-test

\begin{tabular}{lllllll}
\hline Time & $\mathrm{N}$ & Mean & Std.Deviation & T-Test & df & P-Value \\
\cline { 1 - 4 } pre-test & 30 & 13.27 & 1.78 & -11.33 & 29 & 0.0005 \\
\cline { 1 - 3 } post-test & 30 & 15.90 & 1.81 & & & \\
\hline
\end{tabular}

\subsection{Interview Data}

As a part of the study was examining the attitudes of the EFL learners on the use of animation films in the reading class, a semi structured interview using the questions that were designed based on the interview with the colleagues or using her experience. The interview was carried out during the last session of the reading class only with the subjects in the EG. The subjects were interviewed one by one by the researcher as she tried to record their voices. All together four questions were asked. The table below presents the data of the interview and the percent of responses about each. 


\begin{tabular}{|c|c|c|c|}
\hline Questions & & Responses & Frequency \\
\hline \multirow{3}{*}{\multicolumn{2}{|c|}{$\begin{array}{l}\text { 1. Did you enjoy the use of videos in your reading } \\
\text { class? }\end{array}$}} & Yes & 18 \\
\hline & & Almost & 10 \\
\hline & & No & 2 \\
\hline \multirow[t]{3}{*}{2.} & \multirow{3}{*}{$\begin{array}{l}\text { Do you think the use of videos and short films can } \\
\text { help you to read better and more effectively? }\end{array}$} & Yes & 22 \\
\hline & & Almost & 8 \\
\hline & & No & - \\
\hline \multirow{3}{*}{\multicolumn{2}{|c|}{$\begin{array}{l}\text { 3. Did you notice any basic differences between the } \\
\text { approaches used in your reading class and the } \\
\text { ones you had experienced before? }\end{array}$}} & Yes & 26 \\
\hline & & Almost & 4 \\
\hline & & No & - \\
\hline \multirow{4}{*}{\multicolumn{2}{|c|}{$\begin{array}{l}\text { 4. What is the most important pitfall of this } \\
\text { approach? }\end{array}$}} & 1. Taking a lot of time & 8 \\
\hline & & 2. Poor relevance & 8 \\
\hline & & 3. Poor listening & 9 \\
\hline & & 4. Lack of interest & 5 \\
\hline
\end{tabular}

As it can be concluded here, most of the participants in the EG expressed their positive attitudes towards the use of animation films as the activator of their reading knowledge. The responses to the questions revealed that the participants were satisfied with the use of animation films in the reading class. Besides, because of having a completely different language class, they felt happy to adapt themselves to the procedures.

\section{Discussion}

This study investigated the idea that animation films were effective in developing reading comprehension of short stories. The technique was designed to maximize reading comprehension skills through practicing animation film activities. In the hypotheses of the study, the researcher suggested that animation films would bring positive change in the target students' use of reading comprehension texts and their attitudes toward using animation films in learning reading comprehension. To explain, the experimental group recorded higher scores and significantly outperformed the control group who had no practice of the animation films and practiced reading comprehension through the traditional method. In this study, animation films proved the large effects in enhancing the students' ability in the reading comprehension texts. Also, animations attracted the students' attention.

The results of this study confirm the results of previous theoretical and empirical studies (Williamson, 1988.Amer, 1997.campell, 2001.Josef\&Wayers1999.Purnel\&Solman), which referred to animation films as an invaluable technique in the teaching learning process in general and in teaching reading comprehension texts in particular.

Animation films were considered as a technique that presents the story through the movement of events, sound effects and the speech of the characters. So, students can see, hear and interpret any difficult events they do not understand. It is important to mention that the animation films help students who cannot understand the text and hence cannot answer the reading comprehension activities. Also, this technique affects students' attitude toward reading comprehension. The first hypothesis of the study was that there is statistically no significant relationship in the achievement level between the scores of the experimental group who learned reading comprehension of short stories through using animation films and the scores of the control group who learned in the traditional way.

To test this hypothesis, the mean and standard of deviation of the experimental and the control groups' results were compared. The mean of the posttest reflects the effectiveness of animation film as a means of developing reading comprehension activities. This is attributed to the advantages of animation films. These advantages include the cognitive level and the affective level, the two pillar of the educational process. In relevance to the affective level, animation changes the class environment from the traditional one. This new situation attracts and arouses students' desire to focus on the ongoing events of the animated material. Consequently, a student is adapted to learn and to practice cognitive skills. In addition, the animated material is introduced vividly to improve students' abilities to think and acquire reading.

And the second hypothesis was that the EFL learners of the study have a negative attitude towards using animation films in reading comprehension classrooms. Interview results showed that students have positive attitudes toward using animation films in reading class. This means, the technique (animation films) is effective. Therefore, this study proved that using animation films was a useful technique in language learning reading comprehension. This assumption was supported by Londers (1987), who examined the effect of films on reading comprehension knowledge and confirmed that animation films considerably improved the reading comprehension knowledge of the participants.

Besides, the interests of students were directed to films which showed that this technique is helpful in understanding reading comprehension texts, since they draw learners' attention and make boring activities more enjoyable and that exactly what teachers need when presenting new language to catch their learners full attention to raise their interest 
toward the texts. At the same time, films enable students to link the meaning of the texts immediately. when using film in presentation, it is too easy to involve learners actively and to combine the presentation with controlled practice.

Several researchers have suggested that the use of animation films improve reading comprehension, animation films facilitate comprehension. It is believed the use of animation films in the development of instructional materials will promote reading comprehension acquisition (Pan, 2009). Arnhein (1993) argued that the use of animation films enhances the understanding of reading comprehension texts. Studies on the value of animation films in literature and their contribution to the development of reading comprehension activities reported that animation film can serve important functions in the process of presenting readings information to readers (Arizpe \& Styles, 2003; Denburg, 1976; Gambrell \& Jawitz,1993; Haring and Fry1979, Sadoski, 1983.Sanata,1997.Walsh,2003). Arzipe (2003) stated that at the heart of the reading experience is the gap in the texts which has to be filled by the reader in animation films.

\section{Conclusion}

Learning English is very important and it is one of the educational goals in Iran English language learners face the difficulties in mastering English so these learners tend to mask some of their difficulties by restoring to the use of animation film technique. Learners of English at different stages of learning face difficulties and problems in learning English and reading comprehension texts. The learners cannot understand the reading texts easily. It is very difficult for them to answer the reading comprehension activities. EFL students lack the ability of reading comprehension, so answering questions related to a specific text is difficult because of misunderstanding of the text ; therefore, they perform poorly and as a result they dislike English language classes and unfortunately; besides ,the learners leave schools and enter universities where they don't have adequate English proficiency to response the reading comprehension activities. The main cause for this problem is probably because of the traditional way that most teachers use in teaching reading comprehension texts.

\section{References}

Amer, A. (1997). The effect of using film on the reading comprehension of EFL students. International ELT Journal .5, (1), 43-47.

Anderson, R. et al. (1985). Becoming a nation of readers: the report of the commission on reading. US Department of Education, Washington, DC

Arnhein, Z. (1993). Uzaktan egitim yoluyla yabanc dil ogretimi, [Foreign language teaching via distance education], The Turkish Online Journal of Educational Technology- TOJET, 1(1), 92-97.

Arizpe, D. R. \& Style, A. (2003). Using Digital Stories to Improve Reading Comprehension with Spanish Young

Learners of English Language Learning \& Technology, 11(1). p. 87-101. Available: http://lifestyle.ezinemark.com/strategies-for-reading-comprehension-1680421f $07 \mathrm{e}$. html.

Arizipe, W., \& Styles,C. (20003). Effect of Using Photos from Authentic Video as Advance Organizers on Listening Comprehension in an FLES Chinese Class. ELT Methodology (2).

Atwell, C. (1987). Using Multimedia for Effective Entrepreneurial Presentations. The Entrepreneurial Executive, 5(11), 1-11

Bader El Dean, Z. (2009). The Effectiveness of Assisted Reading on Developing Reading Comprehension Strategies for Ninth Graders in Gaza Governorate. Islamic University, Gaza.

Beach, S. (1993). Reading instruction: retiring the bird in the world. Reading Psychology, 14, 333-338.

Beck, M. (1999). Teaching English reading by film in Japan: Teaching how to learn. The Internet TESL Journal, 3(3), Retrieved November 18, 2012 from: http:// www.iteslj.org/Articles/Offner-HowToLearn.html.

Campbell, R. (2001). Reading comprehension with young children. (ERIC Document Reproduction Service NO. ED 451483).

Chiang, M. (2007). Improved reading attitudes and enhanced English reading comprehension via literature circles. Lagos Papers in English Studies, 1(1), 168-183.

Elley, W. (1991). Acquiring literacy in a second language: the effect of book-based programs. Language learning 41 (3), 375-411.

Gambrell, K. \& Jawitz (1993). Potential sources of reading for Japanese learners of English: Preliminary case interviews with five Japanese college students in. the U.S. TESL-EJ, 9, 1-25. Available: www.writing.berkely.edu/teslej/ej35/a3.html.

Gold, J. \& Gibson, A. (2001). Using film to build comprehension [online]. Available at: http://www.readingrockets.org/article/343.

Hargrave, A. C., \& Se'ne'chal, M. (2000). A book reading intervention withadults who have known vocabularies: the benefits of regular reading anddialogic reading. Adult Research Quarterly 15 (1), 75-90.

Haring,et al. (1979). The shorter science and civilization in China: V. 2. Cambridge University Press. 
Harmer, V. (2001). The Effects of Film to College Students' ReadingSkills. Journal of college reading and learning, 29(2) 149-157.

Harste, J. et al.( 1988). Creating classroom for author: the reading-film connection. Heinemann, New Hampshire.

Hennings, D. (1994). Beyond the reading: to read through listening to and reflecting on literature. Phi Delta Kappa educational Foundation, Indiana.

Herron, J. \&Seay, O. (1991). English reading practice through film. Retrieved September 20,2012 from: www.English.com

Herron, W. \& Hanley, M. (2010). Using an authentic and selected film for teaching reading and speaking. Jurnal Ilmiah Dinamika Bahasadan Budaya, 4(2), 54-65.

Herron, Z. (1995). Uzaktanegitimyoluylayabancdilogretimi, [Foreign language teaching via distance education], The Turkish Online Journal of Educational Technology- TOJET, 1(1), 92-97.

Hismanoglu, M. (2005). Teaching English through literature. Journal of Language and Linguistic Studies, 1(1), 53-66.

Joseph, K. M. \&Weyers, L. (1999). New ways in teaching reading. TESOL Quarterly, 22, 6 -7.

Kimmel, M. \& Segal, E. ( 1983). For reading texts Reading books with adults. Dell Publishing, New York.

Londer, J. B. (1987). The Wisdom of Solomon. International Stories. New Jersey: Prentice Hall, 122-124.

McCarthy, M. A. (2001). The impact of using videos on whole language learning in EFL context. Arab World English Journal, 2(2), 5-39.

McCormick, C. (1977). A Preliminary Study of the Effect of Real Time Difficult Word Subtitles on ESL Learning in Taiwan. Master's Thesis. National Taichung University: Taiwan.

McKay, S. (2001). Literature as content for ESL/EFL. In M. Celce-Murcia (Ed.), Teaching English as a second or foreign Language (pp. 319-322). Boston, MA: Heinle \& Heinle.

Mooney, M.M.( 1990). Stories to teach and teaching story: the use of film in learning to teach. Language Arts, 72(4), 276-286.

Nabeel, M.( 1994). The effects of training cognitive and metacognitive strategies on ninth grade students' reading comprehension abilities. Unpublished MA Thesis, University of Jordan, Amman, Jordan.

Neumann, S. B. et al.( 2000). Learning to Read and Write: Developmentally Appropriate Practices for Adults. National Association for Education of Adults, Washington, DC.

Paivio, A.(1986).Mental Representation: A Dual Coding Approach, Oxford university press,new work

Pan, K. (2009). Strategies for Success in Secondary Schools. Britain: Heinemann.

Pezdek, C. et al. (1984). Practical aspects of using video in the foreign language classroom. The Internet TESL Journal, 6(11), 2-4. Available: http://www.iteslj.org/ Articles/canningvideo. html.

Primamore, M. A. (1994). The effects of using film in promoting literacy and enhancing desire to read story. Unpublished MA Thesis,Kean College, New Jersey. (ERIC Document Reproduction ServiceNo. ED367970).

Purnell, M. E. \&Solman, (1991). Technology and teaching English language learners: Using technology to teach reading comprehension skills. London: Pearson.

Queini, H. et al. (2008). Impact of film in the classroom: A case study. The Reading Matrix, 8(10), 139-159.

Rog, L. J. (2001). Effective reading strategies: Teaching adults who find readingdifficult, 2nd ed. Merrill-Prentice Hall, Ohio.

Sadoski, D. (1983). Using video for reading assessment: Opinions of test-takers. TESL Canada Journaula Revue TESL Du Canada, 14(1), 34-40.

Sanata, D. (1997). Strategies of Discourse Comprehension. New York: Academic Press.

Schmitt, C (1997). The effect of video context on foreign language learning Modern Language Journal, 76, 480-9.

Sell, J. P.A. (2005). Why teach literature in the foreign language classroom ? Encuentro, 15(1), 86-93.

Stern, S. L. (2001). An integrated approach to literature in ESL/EFL. In Celce-Murcia (Ed.), Teaching English as a second or foreign Language (pp. 328-345). Boston, MA: Heinle \& Heinle.

Terblanche, L. (2002). Using film: do they enhance students' ability to read? NewYork: New York City Board of Education. (ERIC Document Reproduction Service No. ED465192).

Trelease, J. (1994). The effects of film on the story comprehension and vocabulary knowledge of British school. Reading Improvement, 53(3), 127-136.

Vivas, D. (1996). Using video for reading assessment: Opinions of test-takers. TESL Canada Journaula Revue TESL Du Canada, 14(1), 34-40.

Walsh, M. et al. (2003). The Effect of Using Film on the Students' Achievement 10th Graders in Physics. Nablus: El Nagah University. 
Warwick, E. (1992). How in the world do students read? Delaware: International Reading association.

Williamson, J. (1988). Improving reading comprehension: some current strategies English Teaching Forum 26(1), 7-9. Wood, K. (1994). Hearing voices, using film: finding the power of reading story. Language Arts, 7, 346-349.

Wood, M., \& Salvetti, E. P. (2001). Project Story Boost: using film for students a trisk. The Reading Teacher, 55(1), 76-83.

Zaytoun, A. S. (1988). Different techniques for teaching listening comprehension. English Teaching Forum 24(1), 4649. 